\title{
LA CIUDAD EN LOS POEMARIOS DE JUAN CALZADILLA
}

\author{
GisÈLE Avome MBA \\ Université Omar Bongo \\ spmng13@yahoo.fr
}

Normalmente, no pienso en la ciudad, es más bien la ciudad la que me piensa. Lo que quiere decir que la llevo metida en la cabeza.

JUAN CALZADILLA

\section{RESUMEN}

Contaminación, deshumanización, alienación son las calamidades que el poeta Juan Calzadilla atribuye a la ciudad. Abordamos el estudio de la ciudad literaria tanto desde el punto de vista de su esencia histórica, sociológica y artística. Nuestra contribución pone en escena una estética transgresora para reflejar el absurdo de la vida y propiciar la evasión hacia mundos alternos.

PAlabras Clave: Ciudad imaginaria, deshumanización, alienación, estética de la degradación, poesía, Juan Calzadilla.

\section{RÉSUMÉ}

Contamination, déshumanisation, alinéation: tels sont les maux dont souffrent la ville et ses habitants et que reflète Juan Calzadilla dans les poèmes. Nous avons abordé l'étude de la ville sur le plan littéraire, sociologique et historistique, en mettant également l'accent sur l'aspect estéthique de la dégradation qui traduit le côté absurde de la vie et ouvre la voie vers l'imaginaire. 
Mots-CLEF: Ville imaginaire, déshumanisation, aliénation, esthétique de la dégradation, poésie, Juan Calzadilla.

\section{SUMARY}

Pollution, deshumanization, alienation these are some of the disasters that the poet Juan Calzadilla confer to the city. We deal with the study of the literary city from the writing as well as in the historically, sociologically and artistically point of view. Our contribution stages a transgressor aesthetics in order to show the absurd of life and favour the escape to other worlds.

KEY WoRDS: City imaginary, deshumanization, alienation, aesthetic of the degradation, poetry, Juan Calzadilla.

\section{INTRODUCCIÓN}

Si remontamos a la literatura romántica venezolana, cabe observar una exaltación de la ciudad, bien para negarla o para elogiarla sin medida. Entre los que constituyeron la generación de 1928, Arturo Uslar Pietri (1906- 2001) escoge la ciudad como escenario de sus novelas: Un retrato en la geografía (1962) y Estación de máscaras (1964). Este hecho obedece a cierta lógica ya que, «al comenzar el siglo XX, la composición poblacional nacional se encuentra más en las ciudades que en el campo» ${ }^{1}$. En la novelística del escritor Rómulo Gallegos (1884-1969), la ciudad sigue siendo el escenario primordial en la Trepadora (1925). Entre los integrantes del grupo Viernes ${ }^{2}$ (1938-1947), Luís Fernando Álvarez (1902-1952) usó el entorno urbano en su obra. Ese grupo se verá pronto quebrantado por el clima político de la Venezuela de entonces y el compromiso de algunos de sus integrantes con los movimientos subversivos de izquierda. Ya se visualiza el advenimiento del grupo inicial El Techo de la ballena ${ }^{3}$. Éste plasmó el feísmo ${ }^{4}$ en sus textos y por primera vez aparece la idea de la ciudad como escenario de la violencia y de la alienación, de la miseria y de la deshumanización. Esta nueva mirada suponía la renuncia a una teoría de

${ }^{1}$ Lucca Rafael Arraiz, El coro de las voces solitarias. Una historia de la poesía venezolana, Caracas, Eclipsidra, 2003, p. 338.

${ }^{2}$ El grupo Viernes se impuso entre 1938 y 1941. Será el punto de partida de la modernidad poética venezolana. Los poetas de este grupo, entre los que contamos, Luís Fernando Álvarez, José Ramón Heredia, Andrés Eloy Blanco, Vicente Gerbasi etc... fueron influidos por los movimientos surrealistas francés y latinoamericano. El impacto de este grupo se mide de dos maneras. Primero, el surrealismo introduce la importancia y la preocupación por la imagen verbal a la poesía venezolana. Segundo, el grupo llegó a describir su realidad vivencial por medio de la imagen surrealista.

${ }^{3}$ Fue una agrupación (1961-1969) integrada por artistas y escritores de varias generaciones interesados en una ruptura con la poesía tradicional, actualizando sus lenguajes y el neosurrealismo que él encarnó. Su importancia reside en el impulso que logró comunicar a los lenguajes vanguardistas. Sus integrantes los Balleneros, influidos por los movimientos vanguardistas europeos y con sus posturas agresivas, produjeron una alteración de valores tanto en lo estético como en lo cultural.

${ }^{4} \mathrm{La}$ fealdad ha estado representada en el arte como una manera de reflejar lo feo de la vida o de plasmar con expresividad deformante contraria a los cánones clásicos, aquello que el artista ha querido crear. 
lo bello tal como recogen ciertos autores que presentan el mundo urbano con belleza. Si repasamos la lista de los escritores venezolanos que señalaron aspectos urbanos en sus obras, Juan Calzadilla (1936- ), co-fundador del grupo Techo de la ballena, es considerado como el poeta de la ciudad por excelencia. Como poeta, ensayista y crítico de arte, ha participado en los principales movimientos vanguardistas de su país.

El corpus de esta investigación está representado por los libros: Dictado de la jauría (1962), Principios de urbanidad (1997), Malos modales (1968), Las contradicciones sobrenaturales (1967) y Oh! Smog (1978).

\section{TEORÍA DE LAS REPRESENTACIONES SOCIALES}

La teoría de las representaciones sociales, según el psicoanalista francés Serge Moscovici (1925- ), es una modalidad particular del conocimiento, cuya función es la elaboración de los comportamientos y la comunicación entre los individuos ${ }^{5}$. En otras palabras, es el conocimiento de sentido común que tiene como objetivo comunicar dentro del ambiente social. Además, es esencialmente una teoría del conocimiento social, en la cual el conocimiento se define de una forma amplia de creencias. Asimismo, centra su atención en el movimiento de significados en la sociedad. Por consiguiente, podemos interpretar y dar significado a algo por medio de las representaciones. El significado se refiere al concepto mental o a la idea que se tiene de un objeto o personas, y depende de la relación entre personas, objetos con el mundo. De igual modo, él debe estar unido a un sistema de conceptos e imágenes formados en nuestros pensamientos, los cuales representan al mundo por medio de referencias mentales. Así pues, se establece que las representaciones están sustentadas en la mentalidad, las ideas conscientes e incluso inconscientes. En los textos, podemos ver reflejados nuestros valores, y valga decir que son un discurso construido a través del lenguaje.

Para efectos del análisis, se tomaron como soportes teóricos fundamentales las nociones de las representaciones de Serge Moscovici. Dada la función instrumental de la teoría adopta aquí, resulta necesario indicar cuáles de sus elementos nos servirán para el análisis de las representaciones de la ciudad. En este sentido, nos valdremos de algunas definiciones en primer lugar, para pasar en segundo lugar a destacar su función, finalizando con su proceso de construcción social.

En cuanto al primer aspecto y a las diferentes definiciones que integran el panorama de las representaciones haremos uso de la adoptada por Moscovici en uno de sus escritos:

Las representaciones sociales deberían ser vistas como una forma específica de entender y comunicar lo que ya sabemos... Tienen siempre dos facetas, que son tan interdependientes como las dos caras de una hoja de papel: las facetas icónica y simbólica. Sabemos que representación es igual a imagen/significado; en otras palabras, que hace corresponder a cada imagen una idea y a cada idea una imagen ${ }^{6}$.

\footnotetext{
${ }^{5}$ Serge Moscovici: El psicoanálisis, su imagen y público, Buenos Aires, Editorial Huemul, 1979, pp. 17-18.

${ }^{6}$ Serge Moscovici: Psychologie sociale, Paris, Presses Universitaires de France, 1984, p. 17. Traducción mía.
} 
Dado que nos proponemos analizar las imágenes simbólicas de la ciudad como ser imaginado, resulta conveniente recordar primero que la utilización de las imágenes simbólicas de los seres imaginarios no ha sido un elemento que haya llamado la atención de los teóricos de las representaciones sociales, más preocupados por el análisis de las representaciones sociales dentro de los parámetros metodológicos convencionales de la psicología social.

El segundo aspecto de las representaciones sociales que nos interesa destacar es el de la función de las representaciones sociales: Para ello, volveremos a citar al propio Moscovici:

El propósito de todas las representaciones es el de hacer de algo desconocido o de lo desconocido algo familiar?

Como nos dice Moscovici, las representaciones sociales cumplen la finalidad de transformar un mundo extraño en algo familiar, mudar el desorden y tornar ordenado lo que aparece como caótico, y lo que es imaginado o irreal en algo presente.

Finalmente el tercer elemento a destacar en la teoría consiste en la descripción de los mecanismos a través de los cuales surgen las representaciones de algo a de alguien. Estos dos procesos son el anclaje y la objetivación. Veamos cómo los describe Moscovici:

El primer mecanismo lucha por fijar las ideas extrañas, por reducirlas a categorías e imágenes ordinarias, por situarlas en un contexto familiar. El propósito del segundo mecanismo es su objetivación, esto es, transformar abstracto en algo casi concreto, transferir algo que está en la mente en algo que existe en el mundo físico.Estos mecanismos hacen de lo no familiar algo familiar, el primero transfiriéndolo a nuestra esfera particular donde somos capaces de compararlo e interpretarlo, el segundo reproduciéndolo entre las cosas que podemos tocar y, en consecuencia, controlar ${ }^{8}$.

\section{LA CIUDAD COMO SER IMAGINARIO}

En un ensayo titulado la ciudad entre la imaginación y la ficción (1998), el etnólogo francés Marc Augé (1935- ) estudia los intercambios que se instauran entre la ciudad y el escritor, por lo que «uno ve al autor a través de las ciudades que éste ha evocado: fantasmas que gracias a nuestros recuerdos de lecturas continúan recorriendo sus calles y plazas» ${ }^{9}$. Queda evidente el vínculo estrecho entre la ciudad y el escritor o la sociedad que lo habita. Si la ciudad surge de un acto de escritura, y como tal tiene un lenguaje propio, este lenguaje tiene sus signos específicos. Las ciudades escritas pertenecen al imaginario colectivo. El semiólogo francés Roland Barthes (1915-1980) defiende la necesidad de una semántica de la ciudad, puesto que la ciudad es escritura y su significante está en contraste con la realidad objetiva y descriptiva ${ }^{10}$.

\footnotetext{
7 Serge Moscovici: Psychologie sociale, op. cit., p. 24. Traducción mía

8 Serge Moscovici: Psychologie sociale, op. cit., p. 29. Traducción mía.

9 Augé Marc: El viaje imposible. El turismo y sus imágenes, Barcelona, Editorial Gedisa, 1998, pp. 109-131.

${ }^{10}$ Roland Barthes: Semiología y urbanismo en la aventura semiológica, Barcelona, Planeta de Agostini, 1994, p. 264.
} 
Si tomamos en consideración el desarrollo histórico de la imagen de la ciudad, la presencia del espacio urbano como espacio literario empieza a hacerse notar después de la Revolución Industrial. Si en las primeras épocas de la Revolución Industrial, los realistas se limitan a retratar la ciudad desde un punto de vista exterior, es decir sin comprometerse con las problemáticas que se viven en ellas; a finales del siglo XIX, se establece una nueva poética que privilegia una interpretación de la ciudad inexistente, producto de la fantasía. Las ciudades invisibles o imaginarias llevan a una dimensión espacial en la que el referente real y concreto ha desaparecido por completo. Así, la ciudad se ha convertido en un lenguaje, es decir una creación artística y posee un sistema de símbolos. Y justamente, Roland Barthes plantea la necesidad de leer la ciudad a través de ese proceso y encontrar su imagen.

La ciudad existe en muchas formas. En parte es también una representación material, socialmente construida que habitamos y con la que establecemos una relación sensual y simbólica. Por una parte, la ciudad es también una representación imaginaria, una construcción simbólica discursiva, producto de nuestra imaginación y sobre todo del lenguaje. Habitar la ciudad implica a su vez situarse en un lugar. Nuestra experiencia diaria se informa tanto del dato sensual, perceptual, así como de representaciones de otras experiencias, menos tangibles, no visibles, más lejanas, presentes sólo gracias a la representación. Dichas representaciones se producen en respuestas a las vivencias de la ciudad como realidad sensual, social, pero es partiendo de ellas que intervenimos sobre la ciudad, sobre la sociedad ya sea para reproducirla o modificarla.

Los propósitos de nuestro análisis son varios. Primeramente, entender la ciudad como una entidad múltiple. Es decir, una realidad sicológica e imaginaria, una realidad sensual, una realidad simbólica-discursiva. Segundo, que la vivencia de la ciudad y la intervención sobre ella están mediadas por narraciones de la ciudad construidas con símbolos, imágenes y valores. Tercero, investigar los diversos modos de pensar y «narrar la ciudad que se hallan en los textos». El abordaje propuesto se centra por un lado en la ciudad representada en el discurso, y por otro lado en el discurso de la ciudad en el sentido de que la ciudad habla y asume una voz. En este sentido este planteamiento implica pensar la ciudad como un texto, pero también como un lenguaje, como una escritura, como un acto de leer.

En el caso del poeta venezolano Juan Calzadilla, respecto a su producción poética, su imaginario está configurado por escenarios del contexto urbano. La ciudad es propicia a múltiples interpretaciones. Se convierte en un espacio con valor simbólico. Como ya anunciamos, nuestro propósito es analizar los modos de representación de la ciudad en los poemarios con el objeto de realizar una crítica de orden social. En los poemarios, objeto de nuestro estudio, veremos que el referente urbano ocupa un lugar importante. La ciudad es representada como el hábitat del hombre alienado, de ahí como una atmósfera asfixiante. Más que construir un espacio tópico, se intenta crear una atmósfera urbana donde prevalecen el caos y la deshumanización.

En el poemario, Pavimento con nuevo comensal, se visualizan dos imágenes: la primera, en donde a través de la enumeración caótica coexisten elementos heterogéneos y distantes con la finalidad de construir una especie de objetografía urbana conformada por productos de la sociedad de consumo, cadáveres y desechos de la industrialización. La segunda plasma el espíritu de una época que se define por la prisa y la multitud. Am- 
bas imágenes se superponen gracias a un efecto lúdico con connotación irónica, a través del cual se advierte el rechazo a un modo de vida verbalmente definido a través de le reiteración y la inversión sintáctica de los versos que aparecen destacados en el texto siguiente:

Pronto, sin pérdida de tiempo. Despejemos ya la vía: Apartemos los trastos, el bastón, el cadáver del perro, la polaroid, los papeles regados, la valija, la abolladura triste en la mandíbula del latón, las ruedas al aire, el sorbo de grasa en la piel, las facturas sin pagar, el paraguas junto al silvín, los huesos a la discreción. Objetografía plural que por un instante más besa la goma tibia del pavimento. Sin pérdida de tiempo, pronto, borremos de la ciudad esta mala impresión con la prisa que se pone en sacudir los restos del mantel de la mesa ante la cual, de pie, impaciente, aguarda un nuevo comensal ${ }^{11}$.

En el poema La ciudad 2, se la presenta como un lugar de tránsito. La aparente organización urbana contrasta con su carácter deshumanizante. Allí la vida pierde su carácter de historia para convertirse en un número: «Las distancias se vuelven imaginarias y el tiempo pasa de prisa sin dejar huellas». Por lo tanto es un lugar donde se escapa la memoria:

Aquí el viento pasa de largo. Turbio como boca de perro. Y el sol con sus enjambres no se detiene a poblar el diálogo de las ventanas ${ }^{12}$.

Las contradicciones que animan la ciudad moderna repercuten en el hombre de la calle. Tal situación es retomada en la poesía de Calzadilla. Al nivel formal, se percibe la contradicción entre el intento inútil del hablante de apropiarse de su yo, sugerido a través de la reiteración de los posesivos, y la implacable anulación de sí mismo expresada en el contenido de estos versos:

La ciudad violenta los limites individuales. Ella se apropia del otro a expensas del deterioro humano.

El marco propio de la ciudad es la suma de nuestros cuerpos. Ella crece a expensas del firmamento que excava bajo nuestros pies ${ }^{13}$.

Se crea en la poesía una atmósfera satanizante donde la ciudad se transforma en una bestia cuya acción permea los límites del espacio individual.

En el poema Ciudad, incluido en el poemario Malos Modales, la ciudad es representada simbólicamente como un monstruo que «te tiene en el firmamento de su boca», que «te vigila» $\mathrm{y}$ «alimenta la opacidad triste de tus sueños», «te modela, te reabsorbe» hasta darse cuenta de que ambos hablan el mismo lenguaje del perro. De la misma manera, en La ciudad le va sorbiendo los sesos, la ciudad se impone a tal punto que se desplaza el individuo que ya no es un habitante de ella, sino que por el contrario, es la ciudad quien habita en el hombre en forma de buitre, criatura que le devora las entrañas:

\footnotetext{
11 Juan Calzadilla: Principios de urbanidad, Caracas, Monte Ávila, 1997, p. 15.

12 Juan Calzadilla: Principios de urbanidad, op. cit., p. 89.

13 Juan Calzadilla, Malos modales, Caracas, Ediciones del Techo de la Ballena, 1965, p. 49.
} 
Buitre infame, le grita a la ciudad. Con lo cual, creyendo exorcizarla, sólo la conjura. Y ella tuerce de rumbo, se devuelve y hace acto de presencia, como si hubiese llamada, ahora no para devolverle la calma, sino para devolverle las entrañas. No tenemos cómo echar a estos animales que se han metido en casa. Es difícil si se da a entender que la casa es nuestro cuerpo y los animales los males que se han cebado en é $1^{14}$.

Otra forma de construir la ciudad en el imaginario es ver cómo en medio de la urbe, los individuos pierden el sentido de ubicación, y desaparecen en el anonimato cuanto más se aprietan y se empujan en un pequeño espacio donde el único acuerdo es abrirse paso sin ni siquiera mirarse:

Mira: el que está delante de ti te allana el camino. Puja, empuja, se precipita, avanza, atropella. Excava y detrás de sí un hueco que tú inmediatamente llenas, y a tu turno, tú también pujas, empujas, te precipitas, avanzas, atropellas, para alguien que detrás de ti el hueco que tú dejas $^{15}$.

En medio de la multitud, los hombres pierden su identidad. Sus rostros se enmascaran o se repiten, todos portadores del mismo drama existencial:

Andando por la calle, los espejos están siempre a la mano. A los más fieles, a los más sensibles, se los encuentra en los rostros de la gente, en sus miradas de hoy, en sus cansancios de siglos. Con tal persistencia que ya no se duda de que un rostro comporta muchos rostros en los cuales se faceta, como en un espejo doblado en multitud, ay uno mismo ${ }^{16}$.

El poema Dictado por la Jauría remite a una atmósfera de hostilidad y muestra el rostro terrible de la ciudad. Hay una visión de lo citadino y del espacio urbano. El imaginario de la ciudad ofrece una escenografía configurada por espacios públicos: calles, avenidas, salas de esperas, parques. Los espacios públicos: edificios, oficinas, ascensores, mataderos, carnicerías, cárceles, dispensarios constituyen el ámbito de las actividades sociales. Túneles, alcantarillas y laberintos representan mundos sórdidos que desconciertan y abruman. Dichos espacios representan un mundo donde resulta difícil moverse. La muerte es una presencia que acecha. Un yo lírico, habitante de la «selva de concreto», «metódico hombre tedioso» que vive a diario, reflexiona sobre su condición, se reconoce tras las máscaras, tras los roles impuestos y los oficios que ha de desempeñar dentro de un mundo clausurado en el cual los ciudadanos no tienen escapatoria y sólo logran envilecerse. De ahí la insistencia en las imágenes laberínticas, los espacios sin salida, las actividades rutinarias:

Las costumbres han hecho de mí un hombre abominable impaciente, aguardado todo el día como un funcionario, privado del sueño a quien se le obliga a permanecer amarrado eternamente a su silla .El empresario ha cubierto el cielo con un paraguas, ha hecho del mundo un lugar apto par un crimen, ha reducido increíblemente a los hombres al tamaño de una bala ${ }^{17}$.

14 Juan Calzadilla: Principios de urbanidad, op. cit., p. 35

15 Juan Calzadilla: Malos modales, op. cit., p. 60.

16 Juan Calzadilla: Principios de urbanidad, op. cit., p. 14.

17 Juan Calzadilla: Dictado por la jauría, Caracas, Ediciones Techo de la Ballena, 1962, p. 13. 
En las Contradicciones sobrenaturales, el espacio del poeta es la ciudad, «ciudad rasa», en la que el pánico adquiere la forma precisa, en la que sus habitantes viven como «pájaro en jaula». Es una ciudad invasora que hostiga:

Mis movimientos son tuyos, ciudad, me habitas cruelmente, hostigas mi éxodo, orientas mis pasos hacia los estados de postración, armas mi equilibrio con frágiles que el fuego alimenta $^{18}$.

La ciudad es en la vigilia y el sueño la presencia abrumadora: «Cuando duermes toda la ciudad», «despierta en tu sueño».

Ordenes pone en evidencia la violencia de la que hablamos en Dictado por la jauría, la ciudad encarna la violencia verbal y física:

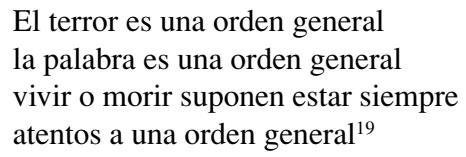

La ciudad se vislumbra como espacio problematizado de encuentros y de desencuentros. La vida en la urbe conduce a la fragmentación de la conciencia, de modo que todo ello proporciona una imagen desintegrada y caótica de la urbe, considerada como lugar de contradicciones y conflictos. La valoración negativa que se desprende de la ciudad deriva de la experiencia de la misma, vivida como espacio desmesurado y alienante que condiciona la vida del hombre y coarta su libertad.

Máscara de papel pone énfasis en la autodenominación del poeta que se convierte en el personaje de su propia representación. Contemplamos un discurso en el que la palabra adquiere un poder superior. Se intuye otra realidad a partir de las imágenes oníricas:

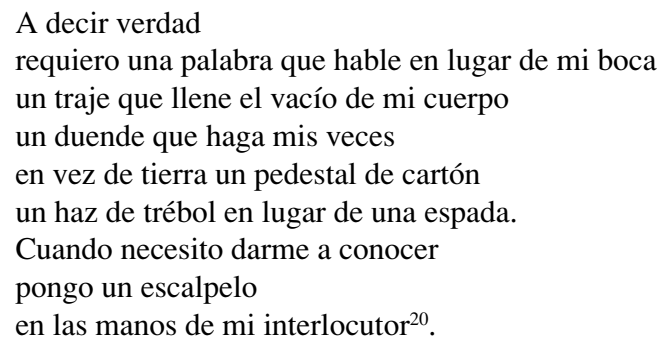

La imagen del poeta se construye sobrepasando los límites de lo humano, y es por ello que paulatinamente se evapora para dejar en su lugar la presencia de una voz. Se otorga la primacía al lenguaje por encima del ser humano. El poeta asume nuevos modos

\footnotetext{
18 Juan Calzadilla: Las contradicciones sobrenaturales, Caracas, Ediciones del Techo de la Ballena, 1967, p. 9.

19 Juan Calzadilla: Las contradicciones sobrenaturales, op. cit., p. 19.

${ }^{20}$ Juan Calzadilla: Las contradicciones sobrenaturales, op. cit., p. 22.
} 
de representación de sí, se construye imaginariamente otra identidad, se representa otra alteridad:

Así que sueño soy manso de carácter

Irascible me desdoblo

en dos o tres en cuatro partes

iguales siempre a mí mismo ${ }^{21}$.

El sueño permite al poeta buscarse otra identidad, construir otro espacio urbano en el que no existe la alienación del hombre.

Varios poderes de la civilización industrial y urbana contemporánea alienan y aturden al hombre. Entre los agentes que provocan la alienación del hombre, hay que contar con el consumismo en la tecnología desarrollada por el hombre. La ciudad sugerida en el $\mathrm{Pa}$ vimento con nuevo comensal del libro Principios de Urbanidad es una urbe caracterizada por una atmósfera contaminada:

Pronto, sin pérdida de tiempo, despejemos ya la vía: Apartemos

los trastos, el bastón, el cadáver

del perro, la polaroid, los papeles

regados, la vajilla, la abolladura triste en la mandíbula del ratón,

las ruedas al aire, el sorbo de grasa en la piel,

las facturas sin pagar,

el paraguas junto al silvín

los huesos a discreción.

Sin pérdida de tiempo, pronto,

borremos de la ciudad esta mala impresión

con la prisa que se pone

en sacudir los gestos del mantel

de la mesa ante la cual, de pie,

impaciente aguarda un nuevo comensal ${ }^{22}$

La ciudad, producto de la industrialización sobrepasa el entendimiento del hombre. La convivencia desarrollada en las modernas ciudades y los rasgos caracterizadores de la ciudad urbana traen elementos negativos. En La ciudad le va sorbiendo los sesos, el protagonista entra en contacto con los aspectos adversos que le acosan. Son los animales, más bien los buitres los que devoran las entrañas:

Todo está dispuesto en la ciudad para que se encuentre que es uno el que está de sobra.

El orden urbano puede pasárselas sin nosotros.

Y he aquí lo que la ciudad argumenta:

Bueno, y qué, ¿por qué no se va usted a otra parte?

\footnotetext{
21 Juan Calzadilla: las contradicciones sobrenaturales, op. cit., p. 22

22 Juan Calzadilla: Principios de urbanidad, op. cit., p. 15.
} 
Es usted el que está demás.

No me eche a mí todas las culpas.

Buitre infame, le grita la ciudad. Con lo cual

creyendo exorcizarla, sólo la conjura

no tenemos cómo echar a estos animales

que se han metido en casa

Es difícil se da a entender que la casa es nuestro cuerpo

$\mathrm{Y}$ los animales los males que se han cebado en él ${ }^{23}$.

Se deja constancia en la ciudad un dolor comunitario, un dolor padecido colectivamente que afecto a todos. Este sufrimiento y lamento unánimes se manifiesta a partir de la pérdida de la esperanza que afecta a todos:

Andando por la calle, los espejos están siempre en la mano.

A los más fieles, a los más sensibles, se los encuentra en los rostros de la gente

en sus miradas de hoy, en sus cansancios de siglos. Con tal persistencia

que ya no se duda de que un rostro comporta muchos otros en los cuales

se faceta, como en un espejo doblado en multitud, ay, uno mismo ${ }^{24}$.

La relación entre el ciudadano y el entorno humano que le rodea queda patente en el texto donde la imagen humana parece al brillo del pavimento:

Normalmente, el brillo que adquiere la calle es el del asfalto

caliente frotado por las llantas y los perros; no es.

Éste es el brillo que mejor sirve de espejo al sujeto que

atraviesa de acera a acera mirando hacia los $\operatorname{lodos}^{25}$.

En el poemario $O h_{i} S m o g$, el poeta describe la miseria, el deterioro físico, moral y humano, así como la decrepitud reinante en la ciudad. El deterioro del espacio está ligado al deterioro de la condición humana: los basureros, los soñadores de pie, los mendigos, los suicidas, todo aquello constituye la deshumanización y la alienación de la ciudad.

En Prólogo de los basureros, la atención del poeta se detiene en un escenario, producto de la industrialización y vector de la decrepitud humana. Es una masa anónima que no puede cumplir con sus anhelos personales porque nadie atiende su existencia:

Barranca abajo coronando los cerros de lata
con el sol retorciéndose en mi espina
encontraré bien extendido
el hule de los sillones baratos
y veré a la carcoma
con sus huevos al hombro
entrar a los túneles del cedro,
aquí donde el salitre por fin

23 Juan Calzadilla: Principios de urbanidad, op. cit., p. 35.

${ }^{24}$ Juan Calzadilla: Principios de urbanidad, op. cit., p. 14.

25 Ibid: Principios de urbanidad. 
los automóviles dan su brazo a torcer

y el jugo de frutas

no anda más por las ramas

y chorrea por los escalones de la depreciación ${ }^{26}$.

El valor negativo de los basureros es símbolo de una realidad funesta. Encarnan los poderes malignos del hombre, su poder de alienación y de cosificación sobre los demás. Las basuras o los lodos representan en la ciudad unas fuerzas sórdidas y anuladoras de la vitalidad humana, y una mención simbólica para referirse a las duras condiciones existenciales del hombre.

La ciudad es un ámbito conflictivo, un lugar para el desencuentro. En Fábula de desencuentro se reelabora sobre el mito de Orfeo y Eurídice. En la ciudad no hay lugar para el beso ni para los vuelos de la fantasía. Los simbólicos muros no propician comunicación, conexión ente unos y otros. Ella y Él, como habitantes de la ciudad, declaran sus formas de sentir la distancia:

Él

$\mathrm{Y}$ aquello que buscamos

es sólo el nombre con que restamos

al miedo la oportunidad de aplazarse.

Ella

Ni siquiera en el sueño

nuestros espíritus llevan alas

las bocas se adhieren al temblor de una voz ajena

cuando se quiere formar las sílabas

del nombre que se ama.

Pero hay cercas de labios llameantes por todas partes

para frenar con sus púas a un cuerpo

que yendo hacia ti, no hace más

que enredarse en su propia presencia ${ }^{27}$.

En Oh!smog aparecen poemas titulados El suicida, lo cual denota el carácter deshumanizante que atribuye el poeta a la ciudad, y en ella a la soledad del hombre al bordo del precipicio y del absurdo. Decenas de personas se presentan, hablan en primera persona, los basureros, los mendigos, los conspiradores, los echados de suertes, el suicida, los ciudadanos, los feroces inválidos y el asesino. Uno enumera condiciones que podrían justificar la muerte voluntaria. El suicida se enfrenta con muelles, cuerdas, smog espeso, postes que lo confrontan consigo mismo y lo hacen balancearse entre la vida y la muerte:

En esta ciudad sólo hay muelles de sombra para partir a medianoche.

Sólo hay claraboyas apagadas para mirar desde la boca de los túneles.

Sólo hay cuerdas para cubrir el ancho de los ataúdes

26 Juan Calzadilla, Oh! Smog, Caracas, Editorial de la Universidad Simón Bolívar, 1977, p. 7

${ }^{27}$ Juan Calzadilla: Oh!smog, op. cit., pp. 57-58. 
y grúas de juguete que describen saltos mortales a mediodía.

Sólo hay el smog espeso del cielo para echar nuestros barcos de almagre ${ }^{28}$.

Se descubre la urbe como espacio para la captación de las inquietudes de los individuos. Se convierte en un espacio decadente. Los mendigos y los pillos llevan mala vida.

En Los mendigos en el Atrio trasluce la pobreza. La urbe no suscita las fantasías de vivir; se contempla un mundo urbano capaz de llevar a la muerte. La contaminación, o sea, lo insoportable del entorno urbano, las acumulaciones de desechos constituyen naturalezas muertas. Los desdoblamientos persisten. La muerte, propia de la urbanidad, aparece por la indigestión que provoca y la solución es escaparse:

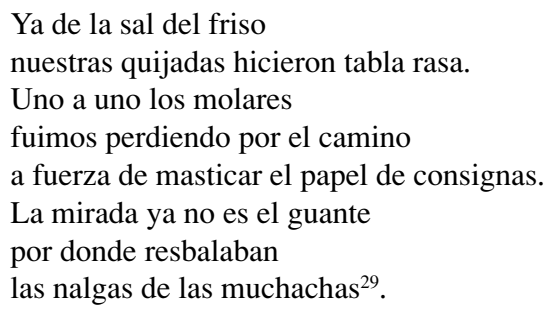

\section{ESTÉTICA DE LA DEGRADACIÓN}

A partir de los estudios de Kant (1724-1804), Lecciones sobre la estética $(1997)^{30} \mathrm{y}$ Hegel (1770-1831 ${ }^{31}$, se ha configurado la estética como una ciencia cuyo objeto es la enunciación de una teoría de la belleza y del arte. La estética hegeliana se mide en la idea de lo bello en general y las formas particulares o históricas que reviste lo bello en el arte. Y dentro de la estética del arte, Hegel va a distinguir entre arte libre y arte servil. Va a realizar una distinción entre lo bello natural y lo bello artístico. Se llega a la conclusión que lo bello artístico supera lo bello natural porque van a estar presente el espíritu y la libertad. De modo que el arte va a ser generado por el espíritu a diferencia de Kant cuyo sentimiento estético ha de ser desinteresado. Este último plantea pues la posibilidad de un discurso estético que consiste en preguntarse por la posibilidad de decir algo con objetividad y universalidad. Esta propuesta kantiana conecta con la estética de nuestro poeta venezolano que considera el arte en un sentido abstracto, sin delimitación geográfica ni temporal.

Otras aportaciones en las que nos vamos apoyar son las de los escritores Diderot (1713-1784) y Rousseau (1712-1778) que confieren a la naturaleza la primacía sobre el arte, al tiempo que destacan el principio de la intuición y de la originalidad en la génesis de la obra de arte, fruto no de la imitación de una realidad exterior sino de la expresión subjetiva del artista.

\footnotetext{
28 Juan Calzadilla: Oh!smog, op. cit., p. 21.

29 Juan Calzadilla: Oh! smog, op. cit., p. 21.

${ }^{30}$ Emmanuel Kant: Lecciones sobre la estética, Madrid, Ediciones Akal, 1997, pp. 44-47.

${ }^{31}$ Georg Hegel, Analítico de lo bello, Caracas, 1989, pp. 121-158.
} 
Por su parte, el filosofo alemán Rosenkranz (1805-1879) en Estética de lo feo (1853) analiza los distintos estadios de manifestación de dicha categoría en la naturaleza, en el hombre y en el arte. Especifica también las distintas modalidades de lo feo: deformación, desfiguración y las que se englobarían en lo que denomina «el infierno estético»: lo criminal, lo espectral, lo diabólico y lo satánico, etc. ${ }^{32}$.

Tratándose de las teorías de la degradación, algunas se enmarcan entre el ser humano, la sociedad y el ambiente que los rodea. El escritor francés Zola (1840-1902) en su teoría del naturalismo según la cual, así como todos los fenómenos del mundo inerte estarían regidos por leyes científicas de causa-efecto, todas las pasiones, sentimientos y emociones de los hombres deberían de estar determinadas, y ante lo cual, propone que la novela deba mostrar las causas que provocan un comportamiento determinado en los personajes.

La poesía venezolana de los años sesenta centra su atención en la realidad social de aquellos tiempos. Ella se caracterizaba, entre otras, por una temática social urbana. Algunos escritores como Juan calzadilla tenían una valoración negativa de la ciudad, vivida como un espacio desmesurado que condiciona la vida del hombre. Esta relación conflictiva del hombre con la ciudad ha llegado a configurar una estética de lo urbano. En su poesía la ciudad se construye mental e imaginariamente, es el artista quien poetiza el espacio urbano y sus habitantes. A veces, se la representa simbólicamente como un monstruo, hace sentir su presencia a través de las acciones y actitudes de sus habitantes. La visión de la urbe que queda materializada a través de los textos es la de una ciudad degradada, alienada y fragmentada. En ella transitan los suicidas, los mendigos, los basureros construidos acorde con el contorno que les rodea. Se define la ciudad como un lugar que acarrea el suicidio, el deterioro físico de la existencia.

La estética de la degradación se evidencia no sólo en el espacio urbano sino también en las condiciones de vida de los habitantes. El autor hace una desmitificación de la ciudad que constituye un elemento podrido por la contaminación y las basuras. Ofrece una descripción de visos apocalípticos: los humos y ácidos.

En El prólogo de los basureros, la atención del poeta se centra en las degradadas condiciones vitales desarrolladas en el espacio urbano escenario y producto de la industrialización. Describe la miseria de un mundo carente de higiene donde «el papel higiénico ondea en los palcos de botellas», un mundo urbano donde queda plasmado el deterioro humano.

El deterioro físico y humano vuelve a evidenciarse en Para orientarse se suben a los postes donde se resaltan las duras condiciones sociales y espirituales de los ciudadanos.

El suicida y Oh! Smog reflejan el deterioro físico del ciudadano. La idea de la ciudad aparece como un lugar de la incomunicación y de la desintegración del ser humano. Otra manera de desnudar la miseria humana de la ciudad es revalorizando poéticamente a los suicidas, los mendigos, los transeúntes construidos a partir de la relación de los sujetos con su entorno. Oh!smog es una forma de reiterar el carácter deshumanizante de la ciudad donde «la diversificación de las actividades y de los medios urbanos provoca una fuerte desorganización de la personalidad, lo que explica la progresión del crimen, del suicidio, de la corrupción y de la locura ${ }^{33}$.

\footnotetext{
32 Karl Rosenkrantz, Estética de lo feo, Madrid, Ollero, 1992, p. 137.

${ }_{33}$ Manuel Castells. La cuestión urbana, Madrid, Siglo Veintiuno de España Editores, 1978, p. 98
} 
El primero de los tres poemas de la serie El suicida es estructurado por una larga enumeración de condiciones que podrían justificar la muerte voluntaria. En el segundo, el suicida se opone a sus demonios: voces y sombras que lo confrontan consigo mismo y lo hacen balancearse entre la vida y la muerte. En el tercero, la ciudad ocupa un lugar entre las múltiples razones que podrían estimular el vicio, convirtiéndolo en un método necesario. La degradación del espacio se relaciona con el deterioro de la condición humana. Los despojos de la sociedad de consumo, los lodos, las basuras sugieren las vivencias de los seres marginados en la ciudad. No se mide sólo el deterioro al nivel temático, puede ser un recurso de que se vale el escritor para crear o recrear una atmósfera de soledad, de tristeza y de abandono:

En esta ciudad sólo hay muelles de sombra para partir a medianoche.

Sólo hay claraboyas para mirar desde la boca de los túneles.

En esta ciudad sólo hay camino para las cintas de las avenidas.

Sólo hay cuerdas para cubrir el ancho de los ataúdes

y grúas de juguete que describen saltos mortales a mediodía.

Sólo hay smog del cielo para echar nuestros barcos de almagre

y conexiones circulares para dirigirnos al centro de la arcilla $^{34}$.

Los mendigos viven muriendo. Son despojos humanos que sobreviven gracias a la abundancia de desperdicios del quehacer urbano. En Los mendigos en el atrio son representados a través de imágenes desgastadas sobre quienes pesa el paso del tiempo, la indiferencia y la desesperanza «fuimos perdiendo por el camino/ a fuerza de masticar/ el papel de las consignas».

Los pillos viven en la muerte y matan la vida a cada instante, en tanto asumen la violencia como identidad:

Y si es una voz de alto

la que por caso se nos da

¿quién duda que un chuzo rápidamente sabe responder por nosotros

mejor que nuestros hombres

como si en el arma

fa falta de sujeto

encontrará su identidad ${ }^{35}$.

La muerte se erige en angustiosa expresión de la existencia contemporánea, bien como final de la vida o como degradación de la existencia, hecho sugerido en la mayoría de los casos:

En esta ciudad hay postes sin raíces

que juegan a mezclar la esperma de sus señales

con el faro de la rutas ultramarinas

y hay rines de llanta negra que suenan a medianoche

con el alarido de los perros ${ }^{36}$.

\footnotetext{
${ }^{34}$ Juan Calzadilla, Oh! Smog, op. cit., p. 91.

35 Juan Calzadilla: Oh!smog, op. cit., p. 49.

36 Juan Calzadilla: Oh! smog, op. cit., p. 91.
} 
El deterioro está de alguna forma presente no sólo en el espacio sino también en la calidad de vida de los habitantes. La degradación física, humana es una manera de expresar el dolor, la incomunicación del ciudadano y su infelicidad en el mundo urbano. Las diferentes maneras de cómo se vislumbran en los textos analizados: derrota, descomposición, desaliento, inutilidad de la existencia, convergen en la sublimación de la muerte. La ciudad en el poeta venezolano puede ser leída como «una matriz de signos en interdependencia con aquellos que la habitan» ${ }^{37}$.

\section{CONCLUSIÓN}

Hemos tratado de describir las posibles representaciones de la ciudad en los poemas y sus modos de leerla. Más que una instancia física, se ha intentado crear una atmósfera urbana donde prevalece el caos y la deshumanización.

\section{BIBLIOGRAFÍA}

\section{Corpus}

Calzadilla, Juan: Dictado por la jauría, Caracas, Ediciones del Techo de la ballena, 1962.

—: Malos modales, Caracas, Ediciones Techo de la ballena, 1965.

—: Las contradicciones sobrenaturales, Caracas, Ediciones Techo de la ballena, 1967.

—: Oh! smog, Caracas, Editorial de la Universidad Simón Bolívar, 1977.

—: Principios de urbanidad, Caracas, Monte Ávila, 1997.

\section{Obras consultadas}

Auge, Marc: El viaje imposible. El turismo y sus imágenes, Barcelona, Editorial Gedisa, 1998.

BARTHES, Roland: Semiología y urbanismo en la aventura semiológica, Barcelona, Planeta De Agostino, 1994.

BERNÁRDEZ, Aurora: Las ciudades invisibles, Madrid, Unidad Editorial, 1999.

Bolaños, María: La ciudad es un estado de ánimo, Valencia, Generalitat Valencia, 1996.

BRIoso SANTOS, Héctor: Estridencia e ironía, El Techo de la Ballena, Sevilla, Universidad de Sevilla, 2002.

BRITTO García, Luís: «La ciudad como escritura» en Quimera, n. ${ }^{\circ}$ 176, enero de 1999.

CAÑAS, Dionisio: El poeta y la ciudad, Madrid, Cátedra, 1994.

CASTELls, Manuel: La cuestión urbana, Madrid, Siglo Veintiuno de España Editores, 1978.

Cilleruelo, José Ángel: Escrituras de la ciudad, Madrid, Atenea Ediciones, 2002.

GuERRA, Lucía: Más allá de la ciudad letrada: crónicas y espacios urbanos, Pittsburg, Instituto Internacional de Literatura Iberoamericana, 2003.

HeGEL, Georg: Lecciones sobre la estética, Madrid, Akal, 1989.

KANT, Emmanuel: Analítica de lo bello, Alicante, Biblioteca de Miguel de Cervantes, 1999.

${ }^{37}$ Lucía Guerra: Más allá de la ciudad letrada: crónicas y espacios urbanos, Pittsburg, Instituto Internacional de Literatura Iberoamericana, 2003, pp. 287-306. 
La Fuente, Antonio y Moscoso, Javier (eds.): Monstruos y seres imaginarios, Madrid, Biblioteca Nacional, 2000.

Moscovici, Serge: Psychologie sociale, Paris, Presses Universitaires de France, 1984.

—: El psicoanálisis, su imagen y público, Buenos Aires, Editorial Huemul, 1979.

RosenKRAnTZ, Karl: Estética de lo feo, Madrid, Julio Ollero, 1992.

ZoLA, Emile: El Naturalismo, Barcelona, Península, 2002. 